\title{
KORELASI KOMPETENSI PEDAGOGIK GURU DENGAN PRESTASI BELAJAR MATA PELAJARAN IPS DI SMP MUHAMMADIYAH PAMIJAHAN KABUPATEN BOGOR
}

\author{
CORRELATION OF TEACHER PEDAGOGIC COMPETENCIES WITH STUDENT LEARNING \\ ACHIEVEMENT IN MUHAMMADIYAH PAMIJAHAN MIDDLE SCHOOL, BOGOR DISTRICT
}

\author{
Wahyu Bagja Sulfemi ${ }^{1}$, \\ Ayu Hopilatul Lestari ${ }^{2}$ \\ STKIP Muhammadiyah Bogor \\ surel: wahyubagja@gmail.com
}

\begin{abstract}
ABSTRAK
Penelitian ini membahas tentang hubungan persepsi peserta didik tentang kemampuan pedagogik guru dengan prestasi belajar peserta didik pada mata pelajaran IPS di SMP Muhammadiyah Pamijahan Kabupaten Bogor (Studi Kasus di SMP Muhammadiyah Pamijahan Kelas VIII Kabupaten Bogor). Penelitian ini bertujuan untuk mengetahui ada atau tidaknya hubungan yang positif antara persepsi peserta didik tentang kemampuan pedagogik guru dengan prestasi belajar peserta didik pada mata pelajaran IPS di SMP Muhammadiyah Pamijahan (studi kasus pada kelas VIII). Jenis penelitian ini adalah penelitian kuantitatif. Penelitian ini merupakan penelitian sampel karena responden yang berjumlah 60 peserta didik diambil dari jumlah populasinya yaitu 170 peserta didik. Pengumpulan data dilakukan dengan menggunakan metode angket atau kuesioner untuk memperoleh data variabel $\mathrm{X}$ yaitu persepsi peserta didik tentang kompetensi pedagogik guru dan metode pengambilan data dari nilai ulangan harian semester ganjil untuk variabel Y yaitu prestasi belajar peserta didik.

Adapun perolehan frekuensi untuk variabel $X$ dengan skor tertinggi 93 dan skor terendah 32, diperoleh rata-rata (mean) 65,90 median 67,5 dan modus 68,49, sedangkan untuk variabel Y skor tertinggi 95 dan skor terendah 61, diperoleh rata-rata (mean) 81,11 median 89,5 dan modus 86,75.

Terdapat atau ada pengaruh positif antara persepsi peserta didik tentang kemampuan pedagogik guru terhadap prestasi belajar peserta didik kelas VIII di SMP Muhammadiyah Pamijahan. Hal ini dapat dibuktikan dengan derajat kebebasan $(\mathrm{dk})=\mathrm{N}-2$ dan $\alpha=0,05$ sebesar 2,000t hitung $(5,391)>\mathrm{t}$ tabel $(2,000)$ maka koefisien korelasi adalah signifikan, nilai $r_{\text {hitung }}$ adalah 0,578 sedangkan $r_{\text {tabel }}$ adalah 0,254 dengan batas signifikan 5\% artinya nilai $r_{\text {hitung }}$ lebih besar dari pada $r_{\text {tabel }}$ yakni $0,578>0,254$. Dengan hasil dinyatakan signifikan dan hipotesis yang diajukan diterima.

Kata kunci : Kompetensi, Pedagogik, dan Prestasi Belajar.
\end{abstract}

\section{ABSTRACT}

This study discusses the relationship of students' perceptions of the pedagogical abilities of teachers with student achievement in social studies at Muhammadiyah Pamijahan Middle School in Bogor Regency (Case Study in Muhammadiyah Pamijahan Middle School in Class VIII Bogor Regency). This study aims to determine whether or not there is a positive relationship between students' perceptions of the pedagogic abilities of teachers and student achievement in social studies at Muhammadiyah Pamijahan Middle School (case study in class VIII). This type of research is quantitative research. This research is a sample study because respondents who numbered 60 students were drawn from the total population of 170 students. Data collection was carried out by using the questionnaire or questionnaire method to obtain variable $X$ data, namely students' perceptions of teacher pedagogical competence and data collection methods from odd semester daily test scores for variable $Y$, namely student achievement. 
The frequency gain for variable $X$ with the highest score of 93 and the lowest score of 32, obtained mean (mean) 65.90 median 67.5 and mode 68.49, while for variable $Y$ the highest score 95 and the lowest score 61, obtained an average mean (mean) 81.11 median 89.5 and mode 86.75. There is or there is a positive influence between students' perceptions of the pedagogic abilities of teachers towards the learning achievement of class VIII students at Muhammadiyah Pamijahan Middle School. This can be proven by the degree of freedom $(d k)=N-2$ and $\alpha=0.05$ of 2,000t count $(5,391)>t$ table $(2,000)$ then the correlation coefficient is significant, the value of $r$ count is 0.578 while rtable is 0.254 with significant limits $5 \%$ means that the calculated value is greater than rtable which is $0.578>$ 0.254 . With the results declared significant and the proposed hypothesis accepted.

Keywords: Competence, Pedagogics, and Learning Achievement.

\section{PENDAHULUAN}

Guru berperan sebagai pengelola proses belajar mengajar, bertindak selaku fasilitator yang berusaha menciptakan proses belajar mengajar yang efektif. Seiring dengan hal ini, komitmen pemerintah untuk menciptakan pendidikan yang lebih bermutu dan berkualitas ditandai dengan lahirnya UU No 20 Th 2003 tentang Sistem Pendidikan Nasional, UU No 14 Th 2005 tentang UU Guru dan Dosen, dan PP No 19 Th 2005 tentang Standar Nasional Pendidikan. Dalam UU dan PP tersebut dinyatakan bahwa pendidik harus memiliki kualifikasi minimum dan kompetensi sesuai dengan bidangnya. Pada undang-undang Nomor 14 Tahun 2005 tentang Guru dan Dosen menyebutkan bahwa yang dimaksud guru adalah pendidik profesional dengan tugas utama mendidik, mengajar, membimbing, mengarahkan, melatih, menilai dan mengevaluasi. Kompetensi Pedagogik merupakan bagian yang tak terpisahkan dari empat kompetensi utama yang harus dimiliki seorang guru, yaitu kompetensi pedagogik, kepribadian, sosial, dan profesional. Berbicara tentang kompetensi pedagogik yaitu kemampuan seorang guru dalam mengelola proses pembelajaran peserta didik. Kompetensi ini mencakup konsep kesiapan mengajar, yang ditunjukkan dengan penguasaan pengetahuan dan ketrampilan mengajar. Mengajar merupakan perkerjaan yang kompleks dan sifatnya multidimensional. Oleh karena itu, guru sangat memerlukan beraneka ragam pengetahuan dan ketrampilan yang memadai yakni sesuai dengan tuntutan zaman dan kemajuan sains dan teknologi.

Seorang guru yang memiliki kompetensi yang maksimal, maka dapat menciptakan persepsi positif di mata peserta didik. Apa yang dilihat peserta didik mengenai kemampuan guru dalam mengajar dapat mempengaruhi persepsi peserta didik pada guru tersebut. Dalam persepsi adakalanya persepsi tersebut baik dan adakalanya juga persepsi tersebut buruk. Bila rangsangan yang diterima peserta didik itu baik, maka peserta didik akan mempersepsikan kemampuan guru dengan baik dan akan berakibat baik pada prestasi belajarnya. Persepsi peserta didik tentang kompetensi guru sangat berpengaruh terhadap prestasi belajar peserta 
didik, sehingga perlu adanya peningkatan kompetensi pedagogik guru untuk mencapai prestasi yang membanggakan. usaha guru untuk meningkatkan prestasi belajar peserta didik, guru diharapkan mampu bertindak sebagai organisatoris pengajaran, menjadi fasilisator belajar peserta didik, dan dalam hal yang teknis guru tersebut mampu membimbing belajar peserta didik. Dengan kata lain guru ikut bertanggung jawab atas keberhasilan belajar peserta didik, meskipun kesemuanya itu kembali kepada peserta didik selaku obyek sekaligus subyek pendidikan.

Mata pelajaran IPS adalah sebagai salah satu mata pelajaran yang diberikan mulai dari SD/MI sampai SMP/MTs, memiliki tujuan untuk mempersiapkan para peserta didik agar menguasai pengetahuan (knowledge), keterampilan (skills), sikap dan nilai (attitudes and values) yang dapat digunakan untuk memecahkan masalah pribadi atau masalah sosial serta kemampuan mengambil keputusan dan berpartisipasi dalam berbagai kegiatan kemasyarakatan agar menjadi warga negara yang baik. ${ }^{1}$

Proses pembelajaran IPS juga belum menghadirkan fenomena-fenomena atau masalahmasalah sosial kedalam kelas. Guru lebih mengejar target materi yang harus diselesaikan tanpa melihat kebermaknaan dari materi IPS itu sendiri, sehingga IPS seolah-olah mempelajari sesuatu yang abstrak dan bersifat hafalan semata tanpa ada relevansi dan aplikasinya dengan kehidupan sehari-hari. Pembelajaran seharusnya menyenangkan dan mencerdaskan peserta didik bukan hanya sekedar menyampaikan materi pelajaran untuk mencapai keberhasilan ujian. Lemahnya proses pembelajaran merupakan salah satu masalah yang dihadapi dunia pendidikan di Indonesia.

Guru mata pelajaran IPS dibentuk untuk mengembangkan kompetensi dan profesionalitas sesuai tuntutan dunia pendidikan yang berkembang pesat, Untuk itu dituntut kreatifitas guru sehingga dapat menumbuhkan karakter guru yang mampu mengembangkan dirinya dan bersama-sama bertanggung jawab terhadap profesinya demi kemajuan pendidikan di berbagai daerah pada umumnya. ${ }^{2}$

"Dalam pendidikan peserta didik akan mengalami kegiatan belajar, dalam proses pembelajaran pasti ada yang dinamakan suatu hasil yaitu, Prestasi belajar yang merupakan suatu masalah yang besifat perenial dalam sejarah kehidupan manusia, karena sepanjang rentang kehidupannya manusia selalu mengejar prestasi menurut bidang dan kemampuan

\footnotetext{
${ }^{1}$ Sapriya, 2009, Pendidikan IPS Konsep dan Pembelajaranya, Bandung: Remaja Rosdakarya, h. 12.

${ }^{2}$ Ahmadi, Lif Khoiru. 2016, Pengembangan Pembelajaran IPS Terpadu, (cet. V, Jakarta : PT. Prestasi Pustakarya Publisher),h. 6
} 
masing-masing". ${ }^{3}$ Tak pelak jika prestasi belajar seringkali menjadi sebagai salah satu tolok ukur akan keberhasilan sebuah pembelajaran dalam dunia pendidikan. Kebanyakan prestasi belajar di berikan dalam bentuk reward atau hadiah, seperti halnya angka yang menjadi perwakilan tingkat keberhasilan peserta didik dalam pembelajaran ataupun berupa benda yang membuat peserta didik yang memiliki prestasi belajar senang dan semakin termotivasi.

Adanya prestasi belajar tentu saja tidak serta merta, namun ada banyak faktor yang mendukung seorang peserta didik mampu memiliki sebuah prestasi, terkadang dorongan atau dukungan yang kuat dari dalam diri peserta didik tersebut untuk mendapatkan sebuah penghargaan atau pun keinginan untuk lebih baik menjadi faktor utama, ada pula dorongan dari pihak ketiga seperti orang tua,lingkungan maupun fasilitas yang memadai, untuk belajar menjadi hal yang mampu menciptakan sebuah prestasi belajar.

Setiap kegiatan belajar mengajar selalu melibatkan dua pelaku aktif, yaitu guru dan peserta didik. Guru sebagai pengajar merupakan pencipta kondisi belajar peserta didik yang didesain secara sengaja, sistematis dan berkesinambungan. Sedangkan peserta didik sebagai subyek pembelajaran merupakan pihak yang menikmati kondisi belajar yang diciptakan guru.

Proses pembelajaran pada dasarnya merupakan interaksi antara peserta didik dan guru. Interaksi yang dibangun haruslah bersifat dua arah dan menempatkan peserta didik bukan sebagai objek pembelajaran tetapi sebagai subjek pembelajaran (student center). Kedudukan peserta didik sebagai subjek pembelajaran berarti peserta didik merupakan individu yang aktif, bukan pasif hanya menerima apa yang diberikan oleh guru.

Guru sebagai seorang pendidik harus mampu mengolah kegiatan belajar mengajar sedemikian rupa sehingga suasana menjadi fun (menyenangkan), demokratis dan terbuka. Seorang guru juga dituntut untuk memiliki kompetensi yang sangat penting yaitu kompetensi profesional, kompetensi pedagogik, kompetensi pribadi dan kompetensi sosial. Kompetensi pedagogik guru adalah kemampuan yang harus dimiliki oleh seorang guru dalam mengelola kegiatan pembelajaran peserta didik yang meliputi pemahaman terhadap peserta didik, perencanaan dan pelaksanaan pembelajaran, serta evaluasi belajar peserta didik.

Guru dituntut setiap saat meningkatkan kompetensinya baik melalui berbagai bahan bacaan, seminar, maupun penelitian yang dilakukan untuk meningkatkan kualitas pembelajaran di kelasnya. Itu semua akan meningkatkan pengetahuan dan kreatifitas anak didiknya. Salah satu wadah yang diharapkan mampu menumbuh kembangkan profesionalitas

\footnotetext{
${ }^{3}$ Arifin Zainal, 2011. Evaluasi Pembelajaran, (Cet. 3. Bandung : PT.Remaja Rosda Karya), h. 12.
} 
dan kompetensi guru adalah berbagai program kegiatn yang diharapkan dapat merealisasikan program-program peningkatan mutu pendidikan dan tenaga kependidikan.

Agar proses pembelajaran dapat dilaksanakan secara efektif dan efisien, serta mencapai hasil yang diharapkan, diperlukan kegiatan manajemen sistem pembelajaran, sebagai keseluruhan proses untuk melaksanakan kegiatan pembelajaran secara efektif dan efisisen. Guru diharapkan membimbing dan mengarahkan pengembangan kurikulum dan pembelajaran secara efektif, serta melakukan pengawasan dalam pelaksanaannya. Dalam proses pengembangan program, guru hendaknya tidak membatasi diri pada pembelajaran dalam arti sempit, tetapi harus menghubungkan program-program pembelajaran dengan seluruh kehidupan peserta didik kebutuhan masyarakat, dan dunia usaha.

Sehubungan dengan hal tersebut, kemampuan guru dalam mengelola pembelajaran dapat dianalisis kedalam beberapa kompetensi salah satu nya yang mencakup pemahaman terhadap peserta didik untuk mengaktualisasikan berbagai potensi yang dimilikinya. Pemahaman terhadap peserta didik merupakan salah satu kompetensi pedagogik yang harus dimiliki guru.

Penilaian terhadap mutu pembelajaran guru berdasarkan tingkat pemenuhan harapan peserta didik tersebut dipandang sebagai persepsi peserta didik tentang mutu pembelajaran guru. Seorang guru yang ketat dan tegas terhadap peserta didiknya akan mempengaruhi persepsi dari peserta didik terhadap guru, baik pengaruh positif maupun negatif. Pengaruh positif yang ditimbulkan dari sikap guru tersebut, misalnya peserta didik akan lebih disiplin saat mengikuti pelajaran guru tersebut karena peserta didik mempunyai persepsi bahwa guru yang bersangkutan disiplin. Namun bila sikap ketat dan tegas itu diterapkan berlebihan maka akan menimbulkan persepsi peserta didik bahwa guru yang bersangkutan kurang bersahabat, akibatnya peserta didik menjadi tertekan dalam mengikuti pelajaran guru yang bersangkutan. Hal tersebut tentu berpengaruh dengan proses belajar peserta didik dan persepsi peserta didik terhadap guru mata pelajaran yang diampu, peserta didik terkadang berpersepsi kurang puas jika diajar oleh guru tersebut. Sehingga akan mempengaruhi pada prestasi belajarnya.

Berdasarkan studi pendahuluan yang telah dilakukan kondisi kemampuan guru di SMP Muhammadiyah Pamijahan sudah terlihat sangat cukup baik, namun masih ditemukan beberapa media pembelajaran atau yang sering kita sebut dengan sarana dan prasarana nya yang masih belum optimal untuk menunjang kegiatan belajar mengajar di SMP Muhammadiyah Pamijahan, sehingga berdampak pada implikasi kompetensi guru yang bersangkutan dalam mengajar di kelas sehingga sering terjadi kurangnya komunikasi yang baik antara peserta didik dengan guru saat kegiatan belajar mengajar khususnya mata 
pelajaran IPS, mengakibatkan peserta didik menjadi malas dalam mengikuti pelajaran dengan baik karena sudah merasa lelah dan bosan. Selain itu juga penulis menemukan hal yang penting lain nya yaitu lemahnya proses penialain dan hasil belajar peserta didik secara berkesinambungan, serta kurang efektif nya evaluasi atas efektivitas proses dan hasil belajar dalam menggunakan informasi hasil penilaian dan evaluasi untuk merancang program remedial dan pengayaan, Sehingga berpengaruh terhadap prestasi belajar peserta didik yang menurun khususnya pada mata pelajaran IPS. Semua itu akan terlihat pada kepatuhan dan loyalitasnya dalam menjalankan tugas keguruannya di dalam kelas dan kependidikannya di luar kelas. Oleh karena itu penulis menetapkan melakukan penelitian mengenai hubungan antara persepsi peserta didik tentang kompetensi pedagogik guru terhadap prestasi belajar peserta didik dalam mata pelajaran IPS di SMP Muhammadiyah Pamijahan.

Lebih lanjut, berdasarkan hasil studi pendahuluan melalui wawancara dengan beberapa orang guru yang mengajar di SMP Muhammadiyah Pamijahan yang berada di Kecamatan pamijahan bahwa pada umumnya prestasi belajar peserta didik itu bervariasi, hal ini dapat dilihat dari nilai ulangan harian peserta didik. Terdapat beberapa peserta didik yang memperoleh nilai yang memenuhi standar kriteria ketuntasan minimal (KKM) yang telah di tetapkan yaitu 75 untuk mata pelajaran Ilmu pengetahuan Sosial. Tetapi terdapat pula peserta didik yang memperoleh nilai di bawah standar KKM. Hal ini dipengaruhi beberapa faktor seperti kemampuan guru dalam menguasai mata pelajaran dan karakteristik peserta didik sehingga ketika menjelaskan dapat mudah dipahami oleh peserta didik, juga lemah nya kemampuan guru dalam menerapkan teori belajar dan prinsip-prinsip pembelajaran yang mendidik pada peserta didik. Pada umunya guru memiliki sifat dan perilaku yang sama, namun yang membedakan setiap guru yaitu dari cara ia mengaplikasikan kompetensi pedagogik nya pada proses pembelajaran dengan baik. Sebenarnya guru tersebut mampu menetapkan berbagai pendekatan, strategi, metode, dan teknik pembelajaran yang mendidik secara kreatif sesuai dengan standar kompetensi guru. Namun karena beberapa faktor yang memengaruhi hal tersebut, sehingga memengaruhi pula pada sebuah persepsi peserta didik dan minat belajar peserta didik yang berdampak kurang baik terhadap prestasi belajar peserta didik. Se-yogya nya guru tersebut mampu menyesuaikan metode pembelajaran yang sesuai dengan karakteristik peserta didik dan memotivasi mereka untuk belajar lebih giat, tetapi karena notabene guru mata Pelajaran IPS ini adalah seorang kepala sekolah di sebuah madrasah di sekitar daerah kecamatan pamijahan sehingga sedikit terhabat nya proses kegiatan belajar mengajar yang berdampak pada prestasi belajar peserta didik. menanggapi hal tersebut kepala sekolah SMP Muhammadiyah Pamijahan akan selalu melakukan 
pembinaan dan perbaikan terhadap permasalahan yang dihadapi seorang guru dalam proses belajar dan mengajar. Tujuan Penelitian ini adalah (1) Untuk mengetahui persepsi peserta didik tentang kompetensi paedagogik guru di SMP Muhammadiyah Pamijahan. (2) Untuk mengetahui prestasi belajar peserta didik dalam mata pelajaran IPS di SMP Muhammadiyah Pamijahan. (3) Untuk mengetahui ada tidak nya Hubungan antara persepsi peserta didik tentang kompetensi pedagogik guru dengan prestasi belajar peserta didik dalam mata pelajaran IPS di SMP Muhammadiyah Pamijahan.

\section{METOLOGI PENELITIAN}

Berdasarkan variabel yang diteliti, masalah yang dirumuskan dan hipotesis yang telah diajukan maka metode penelitian ini menggunakan metode survei dengan pendekatan studi korelasi yang merupakan bagian dari jenis penelitian deskriptif kuantitatif.

Populasi target dalam penelitian ini adalah peserta didik kelas VIII A dan B SMP Muhammadiyah Pamijahan dengan jumlah peserta didik 170 orang. Sampel adalah bagian dari jumlah dan karakteristik yang dimiliki oleh populasi tersebut. Sampel adalah bagian dari populasi yang mempunyai ciri-ciri atau keadaan tertentu yang akan diteliti. ${ }^{4}$ Pengambilan sampel dilakukan dengan simpel random sampling adalah cara pengambilan sampel dari anggota populasi dengan menggunakan acak tanpa memperhatikan tingkatan (strata) dalam anggota populasi tersebut. Hal ini dilakukan apabila anggota populasi dianggap homogen (sejenis). Berdasarkan pendapat arikunto di atas maka, Sampel yang digunakan dalam penelitian ini sebanyak 60 peserta didik dari jumlah populasi yang diambil dari peserta didik SMP Muhammadiyah Pamijahan, hal ini dikarenakan jumlah populasi yang akan diteliti hanya terfokus pada kelas VIII atau penelitian populasi. Dan sistem pengambilan sampel tersebut secara acak atau menggunakan teknik random sampling.

\section{HASIL DAN PEMBAHASAN}

Setelah melakukan penelitian, peneliti mendapatkan hasil studi lapangan berupa data tentang hubungan persepsi peserta didik tentang kompetensi pedagogik guru dengan prestasi belajar peserta didik studi pada mata pelajaran IPS dengan menggunakan instrumen angket yang disebarkan kepada peserta didik kelas VIII di SMP Muhammadiyah Pamijahan Kabupaten Bogor yang berjumlah 60 peserta didik. Sebelum instrumen angket digunakan untuk penelitian maka perlu diuji tingkat valid dan reliabilitasnya. Adapun jumlah pertanyaan

${ }^{4}$ Sugiyono,2009. Metode Penelitian Kuantitatif dan Kualitatif.(Bandung: Alfabeta Bandung).h.4 
yang digunakan dalam uji coba instrumen angket ini sebanyak 20 item pertanyaan, yang terdiri dari 20 item pertanyaan tentang persepsi peserta didik tentang kompetensi pedagogik guru mata pelajaran IPS sedangkan untuk prestasi belajar peserta didik data diambil dari nilai ulangan harian tahun ini. Adapun hasil dari uji coba instrumen tersebut diantaranya 18 pernyataan dinyatakan valid dan 2 pertanyaan tidak valid yaitu no 6 dan 19. Dan instrumen tersebut disebarkan kepada 60 peserta didik. Untuk mengetahui jawaban lebih jelas data hasil penelitian dapat dilihat pada diskripsi sebagai berikut :

Data tentang prestasi belajar peserta didik SMP Muhammadiyah Pamijahan. Untuk mendapatkan data penelitian tentang prestasi belajar peserta didik studi pada mata pelajaran IPS kelas VIII, peneliti mengambil nilai dari hasil belajar ulangan harian semester Ganjil tahun ini, Sedangkan jumlah dari data skor perhitungan prestasi belajar peserta didik studi pada mata pelajaran IPS kelas VIII yang terdiri dari 60 peserta didik sebagai sampel diperoleh skor terendah sebesar 61 dengan skor tertinggi sebesar 95, range skor sebesar 35, skor ratarata (mean) sebesar 81,11, median sebesar 89,5, dan modus sebesar 86,75, sedangkan besar simpangan baku penyebaran data jumlah skor semua pada mata pelajaran IPS yaitu sebesar 448,36, dengan menjumlahkan seluruh skor akhir.

Setelah dilakukan perhitungan data diatas kemudian dapat diuraikan sebagai berikut : Menentukan kualifikasi dan interval nilai dengan cara menentukan range yaitu sebagai berikut : Rentang data sebesar 35, banyaknya kelas sebesar 7, panjang interval sebesar 5, berikut Distribusi Prestasi Belajar Peserta didik Mata Pelajaran IPS Kelas VIII SMP Muhammadiyah dalam bentuk tabel

Tabel Daftar Distribusi Prestasi Belajar Peserta didik Mata Pelajaran IPS Kelas VIII SMP Muhammadiyah

\begin{tabular}{|c|c|c|c|c|c|}
\hline Interval Kelas & $\mathrm{F}$ & $\mathrm{Y}$ & $\mathrm{Y}^{2}$ & F.Y & F.Y $^{2}$ \\
\hline $61-65$ & 1 & 61 & 3721 & 61 & 3721 \\
\hline $66-70$ & 4 & 69,5 & 4830.25 & 278 & 19321 \\
\hline $71-75$ & 12 & 74,16 & 5499,71 & 899,92 & 65996,52 \\
\hline $76-80$ & 14 & 78,92 & 6228,36 & 1104,88 & 87197,04 \\
\hline $81-85$ & 11 & 83,72 & 7009,03 & 920,92 & 77099,33 \\
\hline $86-90$ & 15 & 88,06 & 7754,56 & 1320,9 & 116318,4 \\
\hline $91-95$ & 3 & 93,66 & 8772,19 & 280,98 & 26316,57 \\
\hline Jumlah & 60 & 549,02 & 38984,85 & 4866,6 & 395969,9 \\
\hline
\end{tabular}


Menentukan nilai distribusi prestasi belajar peserta didik mata pelajaran IPS kelas VII di SMP Muhammadiyah Pamijahan yaitu, nilai modus sebesar 86,75, nilai median sebesar 89,5 dan nilai mean sebesar 81,11.

Dari data skor perhitungan prestasi belajar peserta didik studi pada mata pelajaran IPS kelas VIII di atas yang terdiri dari 60 peserta didik sebagai sampel diperoleh skor terendah sebesar 61 dengan skor tertinggi sebesar 95, range skor sebesar 35, skor rata-rata (mean) sebesar 81,11, median sebesar 89,5, dan modus sebesar 86,75, sedangkan besar simpangan baku penyebaran data skor prestasi belajar peserta didik pada mata pelajaran IPS dapat dilihat pada tabel di bawah ini:

Tabel Distribusi Frekuensi Skor Data Y (Prestasi Belajar Peserta didik Pada Mata Pelajaran IPS Kelas VIII) SMP Muhammadiyah Pamijahan

\begin{tabular}{|c|c|c|c|}
\hline No & Interval & Frekuensi Absolut & Frekuensi Relatif \% \\
\hline 1 & $61-65$ & 1 & 1,67 \\
\hline 2 & $66-70$ & 4 & 6,67 \\
\hline 3 & $71-75$ & 12 & 20 \\
\hline 4 & $76-80$ & 14 & 23,33 \\
\hline 5 & $81-85$ & 11 & 18,33 \\
\hline 6 & $86-90$ & 15 & 25 \\
\hline 7 & $91-95$ & 3 & 5 \\
\hline \multicolumn{2}{|c|}{} & 60 & 100 \\
\hline
\end{tabular}

Untuk lebih memperjelas data yang terdapat pada gambar, di bawah ini disajikan diagram batang mengenai prestasi belajar peserta didik kelas VII studi mata pelajaran IPS yaitu:

Gambar Diagram Batang Prestasi Belajar Peserta didik Kelas VIII Studi Mata Pelajaran IPS

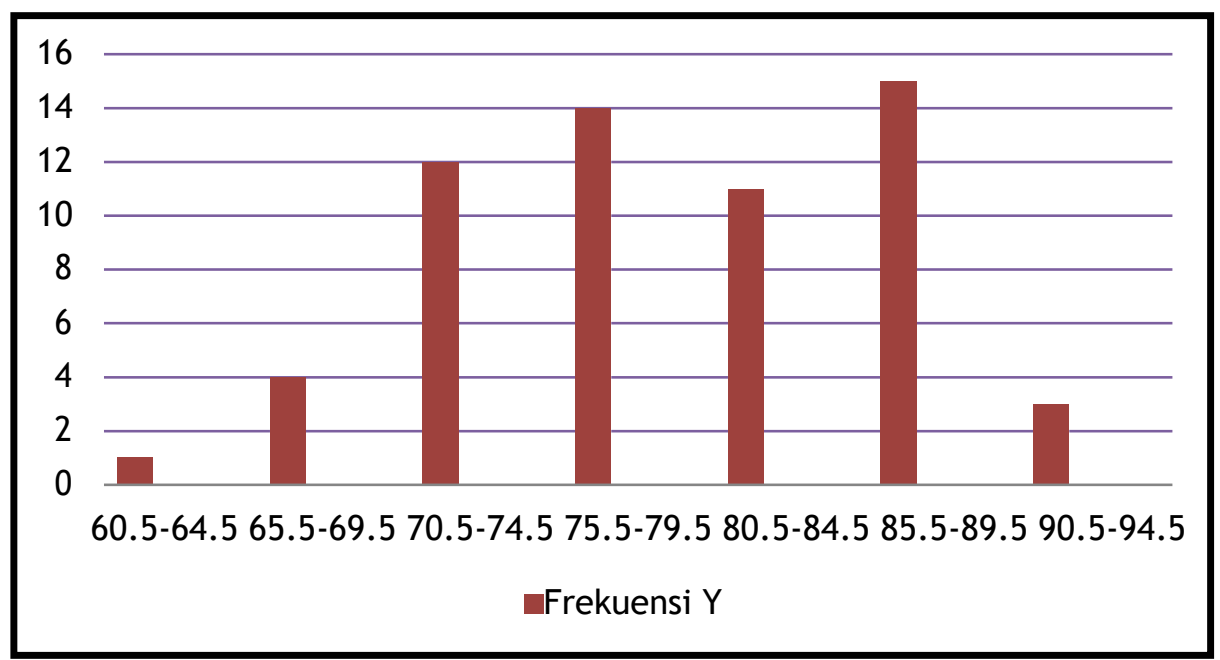


Berdasarkan gambar di atas, dapat dilihat bahwa banyaknya prestasi belajar peserta didik untuk mata pelajaran IPS memiliki nilai antara 76 - 80 dan 86 - 90. Untuk mengetahui kecenderungan prestasi belajar peserta didik tersebut secara keseluruhan dapat diketahui melalui perhitungan persentase frekuensi.

Dari lampiran gambar 4.1 diketahui bahwa nilai yang memiliki rentangan $0-95$. Hasil perhitungan di atas menunjukkan bahwa prestasi belajar peserta didik kelas VIII berkriteria rendah sebesar 1,67\%, berkriteria sedang sebesar 5\%, berkriteria tinggi sebesar $25 \%$, dan berkriteria sangat tinggi sebesar 68,33\%, sehingga nilai dari variabel y yaitu sebesar $68,33 \%$, dengan keterangan kriteria analisis penilaian yang telah di jelaskan pada tinjauan pustaka.

Untuk menentukan nilai kuantitatif persepsi peserta didik tentang kompetensi pedagogik guru studi pada mata pelajaran IPS adalah dengan menjumlahkan skor jawaban angket dari responden.

Dari data skor perhitungan persepsi peserta didik tentang kompetensi pedagogik guru di atas yang terdiri dari 60 peserta didik sebagai sampel diperoleh skor terendah sebesar 32 dengan skor tertinggi sebesar 93, range skor sebesar 62, skor rata-rata (mean) sebesar 65,90, median sebesar 67,5, dan modus sebesar 68,49, sedangkan besar simpangan baku penyebaran data jumlah semua skor pada persepsi peserta didik tentang kompetensi pedagogik guru yaitu sebesar 388,89, dengan menjumlahkan seluruh skor. Setelah dilakukan perhitungan data diatas kemudian dapat diuraikan sebagai berikut :

Menentukan kualifikasi dan interval nilai dengan cara menentukan range yaitu rentang data sebesar 62, banyaknya kelas 7, panjang kelas 9. Berikut Tabel Daftar Distribusi Frekuensi Persepsi Peserta didik Tentang Kompetensi Pedagogik Guru SMP Muhammadiyah Pamijahan

Tabel Daftar Distribusi Frekuensi Persepsi Peserta didik Tentang Kompetensi Pedagogik Guru SMP Muhammadiyah Pamijahan

\begin{tabular}{|c|c|c|c|c|c|}
\hline Interval Kelas & $\mathrm{F}$ & $\mathrm{X}$ & $\mathrm{X}^{2}$ & $\mathrm{~F} . \mathrm{X}$ & $\mathrm{F} . \mathrm{X}^{2}$ \\
\hline $32-40$ & 2 & 35,5 & 1260,5 & 71 & 2521 \\
\hline $41-49$ & 4 & 45 & 2025 & 180 & 8100 \\
\hline $50-58$ & 5 & 54,8 & 3003,04 & 274 & 15015,2 \\
\hline $59-67$ & 19 & 62,7 & 3931,29 & 1191,3 & 74694,51 \\
\hline $68-76$ & 21 & 70,6 & 4984,36 & 1482,6 & 104671,56 \\
\hline $77-85$ & 5 & 79,6 & 6336,16 & 398 & 31680,8 \\
\hline $86-94$ & 4 & 89,2 & 7956,64 & 356,8 & 31826,56 \\
\hline Jumlah & 60 & 473,35 & 29496,99 & 3953,7 & 268509,6 \\
\hline
\end{tabular}

Menentukan Distribusi Frekuensi Persepsi Peserta didik Tentang Kompetensi Pedagogik Guru SMP Muhammadiyah Pamijahan yaitu modus sebesar 68,49, median sebesar 
67,5 dan mean sebesar 65,90. Dari data skor perhitungan persepsi peserta didik tentang kompetensi pedagogik guru di atas yang terdiri dari 60 peserta didik sebagai sampel diperoleh skor terendah sebesar 32 dengan skor tertinggi sebesar 93, range skor sebesar 62, skor ratarata (mean) sebesar 65,90, median sebesar 67,5, dan modus sebesar 68,49, sedangkan besar simpangan baku penyebaran data jumlah keseluruhan skor pada persepsi peserta didik tentang kompetensi pedagogik guru yaitu sebesar 388,89, dengan menjumlahkan seluruh skor persepsi peserta didik tentang kompetensi pedagogik guru di SMP Muhammadiyah Pamijahan Agar lebih jelas maka dapat dilihat pada data berikut :

Tabel Distribusi Frekuensi Skor Data X (Persepsi Peserta didik Tentang Kompetensi Pedagogik Guru SMP Muhammadiyah Pamijahan)

\begin{tabular}{|c|c|c|c|}
\hline No & Interval & Frekuensi Absolut & Frekuensi Relatif $\%$ \\
\hline 1 & $32-40$ & 2 & 3,33 \\
\hline 2 & $41-49$ & 4 & 6,66 \\
\hline 3 & $50-58$ & 5 & 8,33 \\
\hline 4 & $59-67$ & 19 & 31,6 \\
\hline 5 & $68-76$ & 21 & 35 \\
\hline 6 & $77-85$ & 5 & 8,33 \\
\hline 7 & $86-94$ & 4 & 6,66 \\
\hline \multicolumn{2}{|c|}{} & 60 & 100 \\
\hline
\end{tabular}

Untuk lebih memperjelas data yang terdapat pada tabel, di bawah ini disajikan diagram batang mengenai persepsi peserta didik tentang kompetensi pedagogik guru, yaitu:

Gambar Diagram Batang Persepsi Peserta didik Tentang Kompetensi Pedagogik Guru

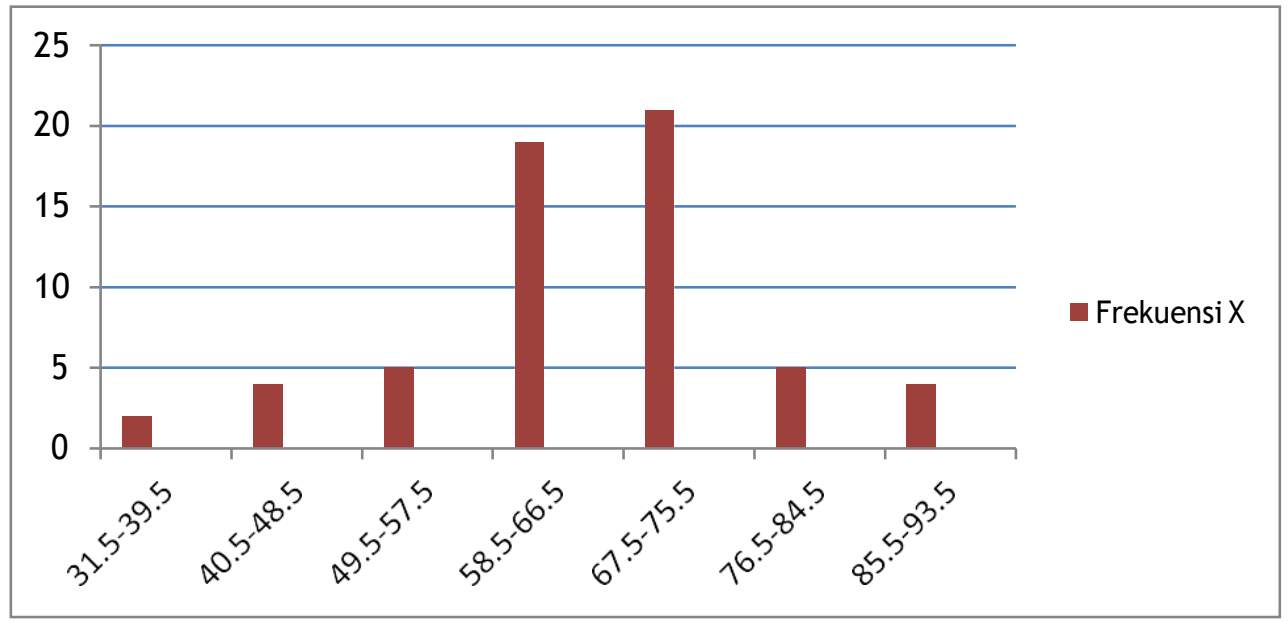

Berdasarkan gambar di atas, dapat dilihat bahwa persepsi peserta didik tentang kompetensi pedagogik guru memiliki nilai antara 68 - 76. Untuk mengetahui kecenderungan 
persepsi peserta didik tentang kompetensi pedagogik guru secara keseluruhan dapat diketahui melalui perhitungan persentase frekuensi dengan rumus perhitungan persentase yaitu :

Dari data diketahui bahwa memiliki rentangan $0-94$. Hasil perhitungan menunjukkan bahwa persepsi peserta didik tentang kompetensi pedagogik guru rendah sebesar 3,33\%, berkriteria sedang sebesar 66,66\%, berkriteria tinggi sebesar 35\%, berkriteria sangat tinggi $55 \%$, sehingga dapat di peroleh nilai rata-rata dari hasil perhitungan akhir yaitu sebesar 55\%.

Data yang sudah terkumpul kemudian peneliti olah untuk mengetahui hubungan persepsi peserta didik tentang kompetensi pedagogik guru dengan prestasi belajar peserta didik studi pada mata pelajaran IPS kelas VIII, maka dilakukan perhitungan korelasi product moment, yaitu: $\mathrm{N}=60, \Sigma X=3952, \Sigma \mathrm{Y}=4857, \Sigma X Y=322794, \Sigma X 2=268660, \Sigma Y 2=396147$, $(\Sigma X) 2=15618304,(\Sigma Y) 2=23590449$. Setelah diketahui antara kedua variabel diatas melalui statistik pearson product moment, maka selanjutnya dimasukkan kedalam korelasi pearson product moment dengan hasil $\mathrm{r}_{\mathrm{xy}}=0.578$

$\mathrm{t}$ tabel pada taraf signifikan 0,05 dengan $\mathrm{dk}=\mathrm{N}-2=60-2=58$ adalah 2,000. Dari hasil perhitungan diperoleh $\mathrm{t}$ hitung 5,391, sedangkan $\mathrm{t}$ tabel 2,000 yang berarti $\mathrm{t}$ hitung $(5,391)>\mathrm{t}$ tabel $(2,000)$ maka koefisien korelasi adalah signifikan.

Selanjutnya untuk menyatakan besar kecilnya sumbangan variabel $\mathrm{X}$ terhadap $\mathrm{Y}$ dapat ditentukan dengan rumus koefisien diterminan sebagai berikut : $\mathrm{KP}=\boldsymbol{r}_{x y}{ }^{2} \times 100 \%=(0,578)^{2}$ $\mathrm{x} 100 \%=0,334084 \times 100 \%=33,38 \%$. Artinya hubungan persepsi peserta didik tentang kompetensi pedagogik guru 33,38\% dan sisanya 66,62\% ditentukan oleh variabel lain atau variasi yang terjadi terhadap prestasi belajar peserta didik. Secara nyata prestasi belajar peserta didik 33,38 \% dipengaruhi oleh persepsi peserta didik tentang kompetensi pedagogik guru.

Untuk menguji keberartiannya sebelum ditafsirkan, maka terlebih dahulu dilakukan uji t pada taraf signifikan, yaitu $:=5,391$

$\mathrm{t}$ tabel pada taraf signifikan 0,05 dengan $\mathrm{dk}=\mathrm{N}-2=60-2=58$ adalah 2,000. Dari hasil perhitungan diperoleh $\mathrm{t}$ hitung 5,391, sedangkan $\mathrm{t}$ tabel 2,000 yang berarti $\mathrm{t}$ hitung $(5,391)>t$ tabel $(2,000)$ maka koefisien korelasi adalah signifikan. Dengan demikian, terdapat hubungan positif antara persepsi peserta didik tentang kompetensi pedagogik guru dengan prestasi belajar peserta didik

Interpretasi data yang disajikan berikut ini mengacu pada permasalahan yang telah dirumuskan pada BAB I. Masalah tersebut mempertanyakan bagaimanakah hubungan yang 
signifikan antara persepsi peserta didik tentang kompetensi pedagogik guru dengan prestasi belajar peserta didik mata pelajaran IPS kelas VIII.

Berdasarkan hasil penelitian di atas juga, bahwa prestasi belajar peserta didik studi pada mata pelajaran IPS kelas VIII dalam kriteria rendah sebesar 1,67\%, kriteria sedang sebesar $5 \%$ kriteria tinggi sebesar $25 \%$ dan dalam kriteria sangat tinggi sebesar 68,33. Dilihat dari rata-ratanya sebesar 81,11 yang termasuk kriteria tinggi. Dengan demikian dapat disimpulkan bahwa prestasi belajar peserta didik kelas VIII SMP Muhammadiyah Pamijahan termasuk dalam kriteria tinggi.

Untuk menunjukkan ada tidaknya hubungan persepsi peserta didik tentang kompetensi pedagogik guru dengan prestasi belajar peserta didik, maka dilakukan uji korelasi product moment. Berdasarkan hasil pengujian $\mathrm{r}_{\mathrm{xy}}$ hitung sebesar 0,578 dan $\mathrm{r}_{\mathrm{xy}}$ tabel pada $\mathrm{N}=60$ dan taraf signifikasi 5\% diperoleh 0,254. Setelah itu dilanjutkan mengukur besar kecilnya sumbangan variabel $\mathrm{X}$ terhadap $\mathrm{Y}$ ditentukan dengan rumus koefisien diterminan dengan hasil 33,38\%. Artinya hubungan persepsi peserta didik tentang kompetensi pedagogik guru $33,38 \%$ dan sisanya $66,62 \%$ ditentukan oleh variabel lain atau variasi yang terjadi terhadap prestasi belajar peserta didik.

Hasil penelitian membuktikan bahwa persepsi peserta didik tentang kompetensi pedagogik guru di SMP Muhammadiyah Pamijahan memiliki kriteria rendah 3,33\%, kriteria sedang sebesar $6,66 \%$, berkriteria tinggi sebesar 35\%, dan berkriteria sangat tinggi sebesar $55 \%$. Dilihat dari rata-rata dalam persepsi peserta didik tentang kemampuan pedagogik guru sebesar 35\% yang termasuk kriteria tinggi. Dengan demikian dapat disimpulkan bahwa persepsi peserta didik tentang kompetensi pedagogik guru SMP Muhammadiyah Pamijahan kelas VIII tergolong dalam kriteria tinggi..

Selanjutnya untuk menguji keberatiannya maka dilakukan uji t hitung. Berdasarkan hasil pengujian $\mathrm{t}$ hitung sebesar 5,391 dan $\mathrm{t}$ tabel dengan derajat kebebasan $(\mathrm{dk})=\mathrm{N}-2$ dan $\alpha$ $=0,05$ sebesar 2,000. Hal ini berarti t hitung lebih besar dari t tabel $(5,391>2,000)$. Hasil pengujian terhadap koefisien korelasi yang diperoleh dari hasil perhitungan bahwa $r_{x y} 0,578$ signifikan. Dengan demikian $\mathrm{H}_{0}$ ditolak sedangkan $\mathrm{H}_{1}$ diterima yang berarti terdapat hubungan yang positif antara persepi peserta didik tentang kompetensi pedagogik guru dengan prestasi belajar peserta didik mata pelajaran IPS kelas VIII di SMP Muhammadiyah Pamijahan. Hal tersebut terbukti dengan hasil nilai $r_{\text {hitung }}$ lebih besar daripada $r_{\text {tabel. }}$

Pembuktian Hipotesis 
Dari hasil perhitungan product moment di atas diketahui bahawa nilai $\mathrm{r}$ hitung adalah 0,578 sedangkan $\mathrm{r}$ tabel adalah 0,254 dengan batas signifikan 5\% artinya nilai $\mathrm{r}$ hitung lebih besar daripada $\mathrm{r}_{\text {tabel }}$ yakni 0,578 >0,254.

Kriteria pengujian, yaitu :

Tolak $\mathrm{H}_{0}$, Jika thitung $>\mathrm{t}$ tabel

Tolak $\mathrm{H}_{1}$, jika $\mathrm{t}$ hitung $<\mathrm{t}$ tabel

$\mathrm{H}_{0}($ Hipotesis nol $)=$ Untuk menyatakan tidak adanya hubungan antara dua variabel $(\mathrm{X}$ dan $\mathrm{Y}$ ) dan $\mathrm{H}_{1}$ (Hipotesis alternatif) = Untuk menyatakan adanya hubungan antara dua variabel (X dan Y)

Dengan demikian nilai $\mathrm{r}$ product moment terdapat hubungan antara persepsi peserta didik tentang kompetensi pedagogik guru dengan prestasi belajar peserta didik, dan $\mathrm{t}$ pada perhitungan taraf signifikan 0,05 dengan $\mathrm{dk}=\mathrm{N}-2=58$ juga terdapat hubungan positif, terbukti $t_{\text {hitung }}(5,391)$ lebih besar daripada $\mathrm{t}_{\text {tabel }}(2,000)$, yakni 5,391 > 2,000 yang berarti $\mathrm{H}_{0}$ ditolak sedangkan $\mathrm{H}_{1}$ diterima.

Untuk menyatakan dan menentukan bobot tingkat hubungan persepsi peserta didik tentang kompetensi pedagogik guru dengan prestasi belajar peserta didik, peneliti menggunakan kriteria besarnya koefisien yang dikutip dari buku acuan Sugiyono.

Berdasarkan kriteria tingkat korelasi di atas, diketahui $r$ hitung adalah 0,578 yang berarti berada di antara 0,400 sampai dengan 0,599 maka dapat dikatakan bahwa hubungan persepsi peserta didik tentang kompetensi pedagogik guru dengan prestasi belajar peserta didik studi pada mata pelajaran IPS kelas VIII di SMP Muhammadiyah Pamijahan, mempunyai korelasi yang sedang karena persepsi peserta didik tentang kompetensi pedagogik guru akan berhubungan dengan prestasi belajar peserta didik.

\section{KESIMPULAN DAN SARAN}

A. Kesimpulan

Setelah peneliti melakukan penelitian dan menganalisis data yang telah diperoleh, baik yang bersifat teoritis maupun lapangan tentang hubungan persepsi peserta didik tentang kemampuan pedagogik guru dengan prestasi belajar peserta didik kelas VIII SMP Muhammadiyah Pamijahan, maka dapat disimpulkan sebagai berikut:

1. Prestasi belajar peserta didik kelas VIII pada mata pelajaran IPS di SMP Muhammadiyah Pamijahan, Nilai rata-rata (Mean) 81,11, nilai tertinggi 95, nilai terendah 61, nilai diatas rata-rata $71,66 \%$ dan nilai dibawah rata-rata $28,33 \%$. Dengan itu dapat disimpulkan 
bahwa prestasi belajar peserta didik kelas VIII pada mata pelajaran IPS memiliki kriteria tinggi.

2. Persepsi peserta didik tentang kemampuan pedagogik guru di SMP Muhammadiyah Pamijahan, Nilai Rata-rata (Mean) 65,90, nilai tertinggi 93, nilai terendah 32, nilai diatas rata-rata $66,66 \%$ dan nilai dibawah rata-rata $33,34 \%$. Dengan itu dapat disimpulkan bahwa persepsi peserta didik tentang kemampuan pedagogik guru memiliki kriteria tinggi.

3. Terdapat atau ada hubungan positif antara persepsi peserta didik tentang kemampuan pedagogik guru dengan prestasi belajar peserta didik kelas VIII di SMP Muhammadiyah Pamijahan. Hal ini dapat dibuktikan dengan derajat kebebasan $(\mathrm{dk})=\mathrm{N}-2$ dan $\alpha=0,05$ sebesar 2,000 thitung $(5,391)>\mathrm{t}$ tabel $(2,000)$ maka koefisien korelasi adalah signifikan,

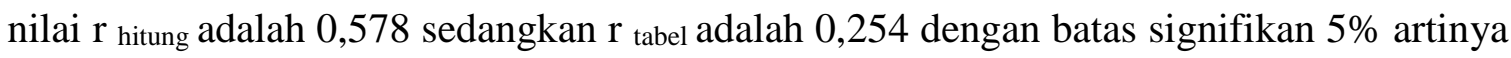
nilai $r$ hitung lebih besar dari pada $\mathrm{r}_{\text {tabel }}$ yakni 0,578 $>0,254$

4. Dengan demikian dapat di katakan bahwa terdapat hubungan yang positif antara persepsi peserta didik tentang kemampuan pedagogik guru dengan prestasi belajar peserta didik pada mata pelajaran IPS studi pada kelas VIII di SMP Muhammadiyah Pamijahan tahun ajaran 2016/2017.

\section{B. Saran}

Sehubungan dengan penelitian yang berjudul hubungan Persepsi peserta didik Tentang Kemampuan Pedagogik Guru dengan Prestasi Belajar Peserta didik (Studi Pada Mata Pelajaran IPS Kelas VIII di SMP Muhammadiyah Pamijahan) Tahun Ajaran 2016/2017, maka peneliti menyarankan hal-hal sebagai berikut untuk ditindak lanjuti, yaitu:

1. Dalam melakukan kegiatan belajar mengajar guru hendaknya berusaha untuk meningkatkan kemampuan pedagogiknya, sehingga dapat menimbulkan kenyamanan bagi peserta didik pada saat kegiatan belajar mengajar berlangsung.

2. Peserta didik merupakan subyek dalam proses belajar mengajar, hendaknya guru dapat mengerti dan mengetahui kondisi peserta didiknya sehingga dapat menciptakan kondisi belajar yang kondusif.

3. Guru harus menciptakan suasana belajar mengajar yang menyenangkan dan tidak terlalu mengekang peserta didik sehingga akan menimbulkan persepsi baik/positif terhadap guru tersebut dan akan berdampak baik pula bagi prestasi belajar peserta didik.

4. Kepala sekolah harus menindak lanjuti peningkatan kompetensi pedagogik guru dengan cara mengadakan pelatihan guru 
5. Guru dituntut untuk selalu inisiatif dan inovasi dalam meningkatkan kompetensi pedagogik.

\section{Referensi}

Ahmadi, Abu. (2007), Sosiologi Pendidikan. Jakarta:Rineka Cipta.

Arsyad, dan Sulfemi, Wahyu Bagja. (2014). Minat Siswa Tentang Keadministrasian dengan Hasil Belajar Administrasi Perkantoran. Edutecno. 9 (2), 40-50.

Arsyad, Arsyad, \& Sulfemi, Wahyu Bagja. (2013). Pengaruh Persepsi Guru Tentang Kemampuan Manajerial Kepala Sekolah dan Kecerdasan Emosional Guru Terhadap Kinerja Guru (Studi Kasus Di SMK Muhammadiyah 6 Kabupaten Bogor).Fascho 2 (1), 1-9.

Badar, Dadan Samsul dan Sulfemi, Wahyu Bagja. (2014). Pengaruh Rasa Percaya Diri dan Motivasi Berprestasi Terhadap Kinerja di Kecamatan Ciampea Kabupaten Bogor. Edutecno. 10 (1), 1-10

Djamarah, Syaiful Bahri. (2008), Psikologi Belajar. Jakarta: PT Rineka Cipta.

Fajartriani, Tia dan Sulfemi, Wahyu Bagja. (2014).Pengaruh Motivasi Kerja Guru dan Iklim Organisasi Terhadap Kinerja Guru SMA Negeri di Kecamatan Cigudeg. Edutecno. 8 (1), $17-26$

Irwantoro Nur, (2016_, Kompetensi Pedagogik, Cet I, Surabaya : Genta Group Production. Mushaf Jejen, 2001, Peningkatan Kompetensi Guru Melalui Pelatihan dan Sumber BelajarTeori dan Praktik, Jakarta: Kharisma Putra Kencana.

Karsiwan, Wawan dan Sulfemi, Wahyu Bagja. (2016). Hubungan Penerimaan Diri Dengan Kinerja Guru SD Di Kecamatan Pamijahan Kabupaten Bogor Edutecno. 15. (1). 110.

Sumaatmadja, Nursid. (2008). Konsep dasar IPS, Jakarta: Universitas Terbuka.

Sapriya, (2009). Pendidikan IPS konsep dan pembelajaranya, Bandung: Remaja Rosdakarya.

Sugiyono, (2009). Metode Penelitian Pendidikan Kuantitatif Kualitatif dan $R \& D$, Bandung : Alfabeta

Sri Awan Asri, Yuliwati. (2011) Bahan Ajar Pendidikan dan Pembelajaran, Jakarta: STKIP Kusuma Negara.

Sulfemi, Wahyu Bagja. (2013). Pengaruh Persepsi Siswa atas Kemampuan Pedagogik Guru dan Motivasi Belajar Siswa Terhadap Prestasi Belajar Ilmu Pengetahuan Sosial Siswa (Survei di SMK Swasta Kabupaten Bogor). Edutecno. 7 (2), 17-26.

Sulfemi, Wahyu Bagja. (2014). Pengaruh Motivasi dan Lingkungan Sekolah Terhadap Prestasi Belajar Sejarah Di SMA Negeri Leuwilang Kabupaten Bogor. Fascho : Kajian Pendidikan dan Sosial Kemasyarakatan 9 (2), 42-52.

Sulfemi, Wahyu Bagja. (2015). Pengaruh Metode Pembelajaran Kontekstual dan Penggunaan Media Video Pendidikan Terhadap Hasil Belajar IPS. Edutecno. 13 (2), 1-10.

Sulfemi, Wahyu Bagja. (2015). Challenges Of Indonesian Teacher Competence in dealing with Asean Economic Cummunity (AEC). Engglis Forum. 1 (1), 69-79

Sulfemi, Wahyu Bagja. (2016). Hubungan Persepsi Peserta Didik Tentang Kompetensi Guru Mata Pelajaran Sejarah dengan Hasil Belajar Mata Pelajaran Sejarah di Kelas X SMA 
Negeri 1 Pamijahan Kabupaten Bogor. Fascho, 5 (2), 52-70.

Sulfemi, Wahyu Bagja. (2016). Hubungan antara Persepsi Guru pada Kepemimpian Kepala Sekolah dan Motivasi Guru dengan Kinerja guru dalam Proses Pembelajaran di SMA Negeri 1 Ciomas. Fascho : Kajian Pendidikan dan Sosial Kemasyarakatan, 5 (1), 36 55 .

Sulfemi, Wahyu Bagja. (2016). Kompetensi Profesionalisme Guru Indonesia dalam Menghadapi MEA. Prosiding Seminar Nasional STKIP Muhammadiyah Bogor. 1 (1), $62-77$

Sulfemi, Wahyu Bagja. (2016). Modul Pembelajaran Ilmu Sosial dan Budaya Dasar Bogor : STKIP Muhammadiyah Bogor.

Sulfemi, Wahyu Bagja. (2017). Analisis Pengaruh Motivasi Dan Disiplin Terhadap Kinerja Guru (Studi Kasus di SMA Negeri 1 Pamijahan Kabupaten Kabupaten Bogor). Prosiding Seminar Nasonal STKIP Muhammadiyah Bogor. 1 (1), 342-357.

Yusdi, Miyam. (2012), Seluk Beluk Profesi Guru, cet.III.Jakarta : PT. Pribumi mekar.

Yusfiriadi, Y., \& Sulfemi, W. B. (2012). Penyelewangan Dana Dalam Dunia Pendidikan. Fascho 1 (1), 1, 9.

Widaryanto dan Wahyu Bagja Sulfemi. (2016). Korelasi Penguasaan TIK Guru dengan Kemampuan TIK Siswa. Edutecno. 14. (1). 1-10. 